\title{
The Contribution of Fluorine 18F-FDG PET/CT to Lung Cancer Diagnosis, Staging and Treatment Planning
}

Flor ${ }^{8}$ F-FDG PET/BT'nin Akciğer Kanseri Tanı, Evreleme ve Tedavi Planlamasına Katkısı

\author{
(D) Emine Budakl, (D) Gürsel Çok², (D) Ayşegül Akgün33 \\ University of Health Sciences, Izmir Dr. Suat Seren Chest Diseases and Surgery Training and Research Hospital, Clinic of Nuclear Medicine, \\ Izmir, Turkey \\ 2Ege University Faculty of Medicine, Department of Chest Diseases, Izmir, Turkey \\ 3Ege University Faculty of Medicine, Department of Nuclear Medicine, Izmir, Turkey
}

\begin{abstract}
Objective: Lung cancer is the most common cause of cancer-related death throughout the world, and the correct choice of treatment based on early diagnosis and staging increases the chance of survival. The present study aims to investigate the contribution of fluorine 18-fluorodeoxyglucose-positron emission tomography/computed tomography (18F-FDG PET/CT) to the management of lung cancer.

Methods: In this study, 50 patients who underwent 18F-FDG PET/CT for lung cancer diagnosis and staging between February 2012 and February 2014 were included. The maximum standardized uptake value (SUV max $_{\text {) }}$ ) of the primary lung lesion along with other findings of $18 \mathrm{~F}-\mathrm{FDG}$ PET/CT and the results of histopathologic and conventional examinations were evaluated retrospectively. The mean survival time of patients was determined, and the findings were compared by using statistical methods.

Results: Histopathologic examinations revealed 51 lung cancers in 50 patients. The sensitivity, accuracy and positive predictive value of 18 F-FDG PET/CT in detecting primary malignancy were $94 \%, 94 \%, 100 \%$, respectively. Adenocarcinoma ( $n=23$, $16.8 \pm 13.5)$ and squamous cell carcinoma $(n=15,17.9 \pm 5.6)$ did not differ significantly regarding their mean $S U V_{\text {max }}$ values $(p=0.2)$. A statistically significant positive correlation $(r=0.4)$ was identified between tumor size and SUV $V_{\text {max }}$ value for 51 tumors $(p=0.002)$. The 18F-FDG PET/CT result was true negative in nine, false positive in six, true positive in two, and false negative in four patients who underwent histopathologic evaluation of their lymph nodes. The 18F-FDG PET/CT changed treatment planning in $34 \%$ of the patients. No significant relationship was identified between $S U V_{\max }$ value of the tumor and patient survival in patients $(\mathrm{p}=0.118)$.

Conclusion: The present study concluded that PET/CT was an efficient method in the diagnosis and staging of lung cancer since it provided useful information in addition to conventional methods. It was also observed that PET/CT scanning resulted in a change in therapeutic plans in the majority of patients. However, there was no statistically significant relationship between survival and the SUV $\max$ of the primary mass.

Keywords: Lung cancer, positron emission tomography, survival analysis
\end{abstract}

Address for Correspondence: Emine Budak MD, University of Health Sciences, İzmir Dr. Suat Seren Chest Diseases and Surgery Training and Research Hospital, Clinic of Nuclear Medicine, Izmir, Turkey

Phone: +90 5307757306 E-mail: eminetkn4@gmail.com ORCID ID: orcid.org/0000-0002-5632-2741

Received: 02.12.2017 Accepted: 06.03.2018

${ }^{\circ}$ Copyright 2018 by Turkish Society of Nuclear Medicine

Molecular Imaging and Radionuclide Therapy published by Galenos Yayınevi. 


\section{Öz}

Amaç: Akciğer kanseri, tüm dünyada kansere bağlı ölümlerin en sık nedenidir. Erken tanı ve evrelemeye bağı doğru tedavi seçimi akciğer kanserinde sağkalımı artıran bir faktördür. Amacımız akciğer kanseri yönetimine flor 18-fluorodeoksiglukozpozitron emisyon tomografisi/bilgisayarlı tomografinin (18F-FDG PET/BT) katkısını araştırmaktır.

Yöntem: Çalışmamıza Şubat 2012-Şubat 2014 tarihleri arasında akciğer kanseri tanı ve evrelemesi amacıyla 18F-FDG PET/BT yapılan 50 hasta dahil edildi. 18F-FDG PET/BT'de akciğerde saptanan primer lezyonun maksimum standart tutulum değeri (SUV $\mathrm{V}_{\text {maks }}$ ) ve diğer bulguları ile histopatolojik ve konvansiyonel yöntem sonuçları retrospektif olarak değerlendirildi. Hastaların ortalama sağkalım süresi belirlendi. İstatistiksel yöntemler kullanılarak bulgular karşılaştıııdı.

Bulgular: Elli hastada histopatolojik olarak toplam 51 akciğer kanseri saptandı. 18F-FDG PET/BT'nin primer maligniteyi saptamada duyarlılık, doğruluk ve pozitif prediktif değeri sırasıyla \%94, \%94, \%100 saptandı. Adenokarsinom ( $\mathrm{n=23,}$ $16,8 \pm 13,5)$ ve skuamöz hücreli karsinom $(n=15,17,9 \pm 5,6)$ ortalama SUV maks değeri açısından anlamlı bir farklılık göstermedi $(p=0,2)$. Elli bir tümör için tümör boyutu ile $S U V_{\text {maks }}$ değeri arasında istatistiksel olarak anlamlı pozitif korelasyon $(r=0,4)$ mevcuttu ( $p=0,002)$. 18F-FDG PET/BT, histopatolojik olarak lenf nodu değerlendirilen hastaların; dokuzunda gerçek negatif, altısında yanlış pozitif, ikisinde gerçek pozitif ve dördünde yanlış negatifti. ${ }^{18 F-F D G ~ P E T / B T, ~ h a s t a l a r ı n ~ \% 34 ' u ̈ n d e ~ t e d a v i ~ p l a n ı n ı ~}$ değiştirdi. Tümörün SUV maks değeri ile hasta sağkalımı arasında anlamlı bir ilişki yoktu $(p=0,118)$.

Sonuç: Çalışmamızda PET/BT'nin konvansiyonel yöntemlere ek önemli bilgiler sağlayarak akciğer kanseri tanı ve evrelemesinde etkin bir yöntem olduğu sonucuna varıldı. Ayrıca PET/BT'nin evrelemeye katkısıyla hastaların önemli bir kısmında tedavi planında değişikliğe neden olduğu görüldü. Ancak primer kitlenin SUV maks değeri ile hastaların sağkalımı arasında istatistiksel olarak anlamlı ilişki saptanmadı.

Anahtar kelimeler: Akciğer kanseri, pozitron emisyon tomografi, sağkalım analizi

\section{Introduction}

Lung cancer is the most frequent malignancy throughout the world since 1985 (1) and the leading cause of cancerrelated death in both men and women (2). Curative treatment can be offered to lung cancer patients with early diagnosis, in whom computed tomography $(\mathrm{CT})$ is the first diagnostic tool (3). One of the most important prognostic factors in lung cancer is tumor stage. Hence, proper staging is very important when determining prognosis and choosing appropriate treatment. T-staging is based on CT findings, although this modality may be unable to distinguish a tumor from atelectasis or show disease extent. Fluorine 18-fluorodeoxyglucose positron emission tomography/CT (18F-FDG PET/CT) is an effective method for the diagnosis, staging, evaluation of treatment response, follow-up for recurrence and re-staging of lung cancer. In our retrospective study, we investigated the contribution of 18F-FDG PET/CT to lung cancer diagnosis, staging and management, as well as the prognostic and survival effects of the maximum standardized uptake value $\left(S U V_{\text {max }}\right)$ of the primary lesion in an 18F-FDG PET/CT.

\section{Materials and Methods}

The present study included 50 patients who have been referred to Ege University Faculty of Medicine, Department of Nuclear Medicine between February 2012 and February 2014, and who have undergone 18F-FDG PET/CT scanning for the diagnosing and staging of lung cancer. Patients were injected intravenously with 250$400 \mathrm{MBq}$ of $18 \mathrm{~F}-\mathrm{FDG}$ at least four hours after fasting for 18F-FDG PET/CT imaging. Approximately one hour after the tracer injection, PET and CT scans were obtained using a PET-CT scanner (biograph high-definition 16-slice $\mathrm{CT}$, Siemens Healthcare, Erlangen, Germany), and the PET and CT images were loaded onto three-dimensional workstations. Visual and semi-quantitative evaluation of the lesions observed on 18F-FDG PET/CT were carried out. In case of non-physiologically enhanced areas of activity associated with soft/bone tissue on $\mathrm{CT}$, the finding was identified as "PET lesion", and these PET lesions were interpreted as malignant if either the $S U V_{\max }$ value $>2.5$ or when the FDG uptake was significantly higher than the background tissue. Adrenal gland lesions with a higher FDG uptake than the liver were considered as malignant. A total of 30 patients or their close relatives were accessed to assess survival. One of those 30 patients had synchronous double primary lung cancers. The correlation between the $S U V_{\text {max }}$ value of the primary lesion and patient survival was evaluated. The findings of 18F-FDG PET/CT were compared with radiologic and histopathologic results as well as the final clinical decisions and the determined stages.

\section{Statistical Analysis}

The IBM SPSS V 21.0 software was used for statistical analysis. Kolmogorov-Smirnov and Shapiro-Wilk (S-W) tests were utilized for normality analysis of data distribution, and Mann-Whitney $U$ test was applied to determine the differences between the two groups in case of non-normal distribution. A Spearman's rho correlation test was utilized to investigate the correlation between the parameters, and the Kaplan Meier method was used for survival analysis. The differences in survival curves taking different variables into account were tested by using the log-rank test. 


\section{Results}

This study included 50 patients (46 males, four female,

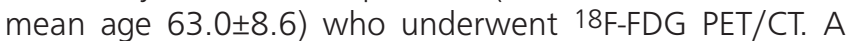
histopathologic diagnosis of lung cancer was obtained in all patients. There were 51 tumors in 50 patients since one patient had synchronous double primary lung cancers that have been diagnosed as adenocarcinoma. The histopathologic results of the lung lesions revealed 23 adenocarcinomas, 15 squamous cell carcinomas (SCC), four small-cell lung cancers (SCLC), two large-cell neuroendocrine carcinomas, one adenoid cystic carcinoma, one carcinoid tumor and five non-SCLC [(NSCLC), with no specific classifications]. Patient and tumor characteristics are summarized in Table 1. In terms of detecting malignancy, the 18F-FDG PET/CT yielded true positive results in 48 and false negative findings in three cases out of the 51 tumors. The tumor size and histopathologic features of these three false negative lesions were $0.6 \mathrm{~cm}$ adenocarcinoma (SUV $\left.V_{\text {max }}: 1.4\right), 1.3 \mathrm{~cm}$ adenocarcinoma (SUV $\left.V_{\text {max }}: 1.6\right)$ and $1 \mathrm{~cm}$ carcinoid tumor (SUV $\left.\max : 0.8\right)$. In the patient who had synchronous double primary lung

Table 1. Patient-tumor characteristics and the impact of positron emission tomography/computed tomography on patient management

\begin{tabular}{|c|c|c|c|c|c|c|}
\hline No & Sex & Histologic subtype & $\begin{array}{l}\text { Tumor diameter } \\
(\mathrm{cm})\end{array}$ & Tumor SUV $_{\max }$ & $\begin{array}{l}\text { Patient survival } \\
\text { (month) }\end{array}$ & $\begin{array}{l}\text { Impact of PET/CT scan } \\
\text { on patient management }\end{array}$ \\
\hline 1 & M & $A C$ & 1 & 9.3 & 6 & - \\
\hline \multirow[t]{2}{*}{2} & M & $A C$ & 2.7 & 18.6 & 8 & - \\
\hline & & $A C$ & 0.6 & 1.4 & 5 & - \\
\hline 3 & $M$ & $A C$ & 6.4 & 61.8 & 11 & - \\
\hline 4 & M & SCC & 4.5 & 29.6 & & - \\
\hline 5 & M & $A C$ & 4.4 & 34.2 & 20 & - \\
\hline 6 & $M$ & NSCLC & 5.9 & 13.7 & & - \\
\hline 7 & M & SCC & 3.5 & 14.3 & & - \\
\hline 8 & M & LCNEC & 1.6 & 15.8 & 15 & - \\
\hline 9 & M & CARCINOID & 1 & 0.8 & 17 & - \\
\hline 10 & M & $A C$ & 5.5 & 21.3 & 8 & $+(4 a)^{\prime}$ \\
\hline 11 & M & NSCLC & 3.3 & 19.7 & 7 & $+(2)^{*}$ \\
\hline 12 & M & $A C$ & 5.2 & 19.4 & & $+(4 b)^{\prime}$ \\
\hline 13 & $\mathrm{M}$ & SCC & 6 & 15.5 & 19 & - \\
\hline 14 & M & $A C$ & 3.7 & 10.9 & 15 & - \\
\hline 15 & $\mathrm{M}$ & SCC & 11.5 & 14.5 & 1 & - \\
\hline 16 & M & $A C$ & 12.3 & 14.4 & 8 & - \\
\hline 17 & $\mathrm{~F}$ & SCLC & 6.1 & 14.8 & & - \\
\hline 18 & M & SCC & 4 & 14.9 & 6 & - \\
\hline 19 & M & $A C$ & 2 & 12.3 & 7 & - \\
\hline 20 & $M$ & $A C$ & 1.5 & 10.3 & & - \\
\hline 21 & $M$ & SCLC & 3.6 & 10 & 1 & $+(2)^{*}$ \\
\hline 22 & $\mathrm{M}$ & SCC & 9.5 & 19.2 & 14 & - \\
\hline 23 & $\mathrm{M}$ & LCNEC & 2.7 & 17 & 15 & $+(4 c)^{\prime}$ \\
\hline 24 & $\mathrm{M}$ & $A C$ & 3.7 & 20.9 & & $+(3)^{*}$ \\
\hline 25 & $\mathrm{M}$ & SCC & 4.6 & 24.7 & 12 & - \\
\hline 26 & $M$ & SCC & 11 & 20.5 & & $+(2)^{*}$ \\
\hline 27 & $M$ & SCC & 8 & 26.7 & & $+(3)^{*}$ \\
\hline 28 & $\mathrm{~F}$ & $A C$ & 2.3 & 9.8 & & - \\
\hline 29 & M & SCC & 3 & 7 & & $+(6)^{\prime}$ \\
\hline
\end{tabular}


Table 1. Continued

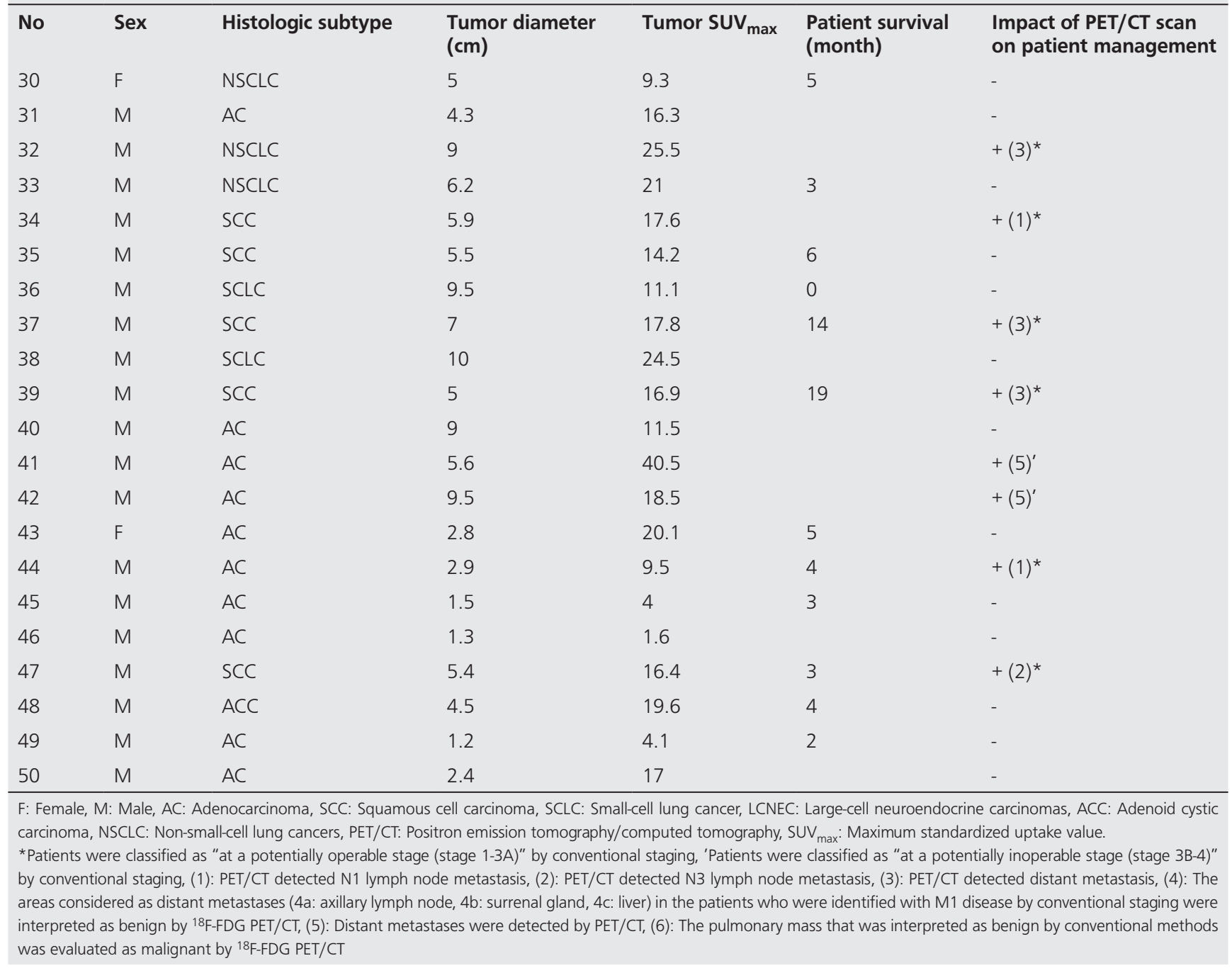

cancers, the adenocarcinoma of $0.6 \mathrm{~cm}$ (SUV $\max : 1.4)$ had a false negative finding whereas the $2.7 \mathrm{~cm}$-sized (SUV max: 18.6) adenocarcinoma was detected. The sensitivity, accuracy and positive predictive value of 18F-FDG PET/CT in detecting primary malignancy were calculated as $94 \%$, $94 \%$ and $100 \%$, respectively. The mean SUV max values of adenocarcinoma $(n=23)$ and SCC $(n=15)$ lesions was $16.8 \pm 13.5$ and $17.9 \pm 5.6$, respectively. These two types of lung cancer were similar in terms of SUV max values $(p=0.2)$. The correlation between tumor diameter and $S U V_{\max }$ was evaluated for all tumors. The mean tumor diameter of the 51 tumors was $5.0 \pm 2.9 \mathrm{~cm}$. Tumor sizes ranged from 0.6 $\mathrm{cm}$ to $12.3 \mathrm{~cm}$. A statistically significant positive correlation $(r=0.4)$ was identified between tumor size and SUV $\max$ $(p=0.002)$. Two patients had post-obstructive atelectasis due to the tumor, and the 18F-FDG PET/CT was able to distinguish between the tumor and the atelectasis owing to an intense FDG uptake in the tumor area. Thus, the tumor size was correctly calculated (Figure 1). The histopathologic results of the lymph nodes were compared with nodal staging according to 18F-FDG PET/CT. Histopathologic evaluation of the lymph nodes was performed on 21 patients. The 18F-FDG PET/CT findings were interpreted as true negative in nine, false positive in six, true positive in two and false negative in four patients. In this regard, 11/21 $(52 \%)$ of the patients were correctly staged by $18 \mathrm{~F}-\mathrm{FDG}$ $\mathrm{PET} / \mathrm{CT}$, while 4/21 (19\%) patients were incorrectly downstaged and 6/21 (28\%) were incorrectly up-staged by PETCT. Within the group of 15 histopathologically NO patients, the 18F-FDG PET/CT was NO in nine (true negative) while it was false positive in the remaining six patients. 18F-FDG PET/CT identified subcarinal, right hilar and left interlobar hypermetabolic lymph nodes in one of the six patients with a false positive result (Figure 2). Thus, the patient was staged as N3 on 18F-FDG PET/CT. Histopathologically, these lymph nodes were assessed as anthracosis and the 

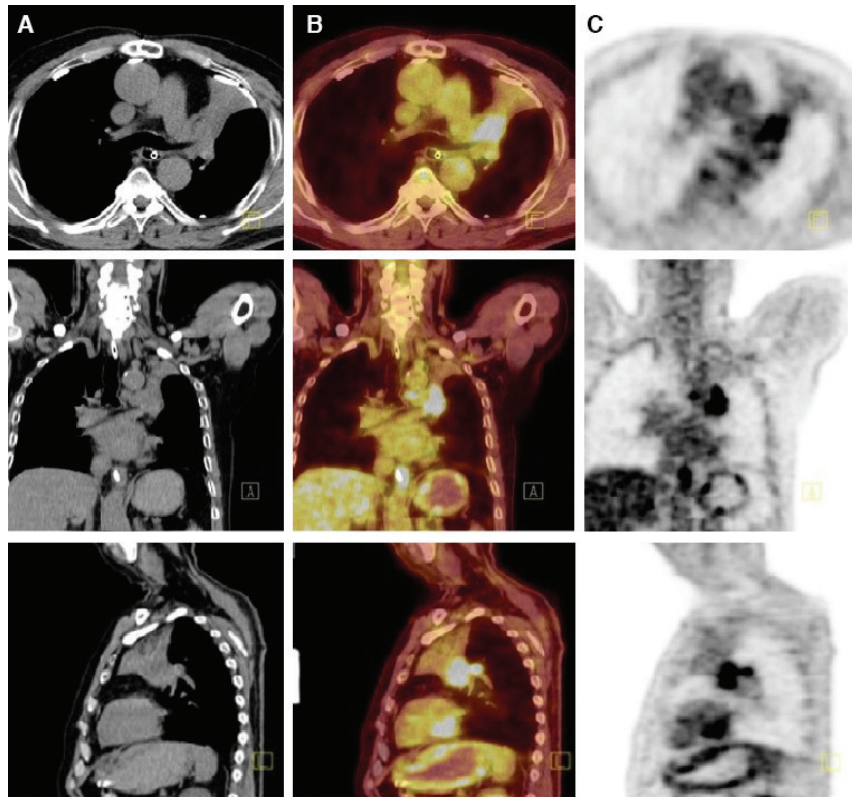

Figure 1. Axial, coronal, and sagittal CT images (A), fused PET/CT images (B) and PET images (C) of the patient with small cell lung carcinoma. The tumor size could not clearly be assessed on CT images. The fused PET/ $\mathrm{CT}$ images enables differentiation of tumor and atelectasis areas due to intense FDG uptake of the tumor area [tumor maximum standardized uptake value $\left(S U V_{\text {max }}\right): 10$, atelectasis $\left.S U V_{\text {max }}: 3.7\right]$, thus, the tumor size has been correctly calculated
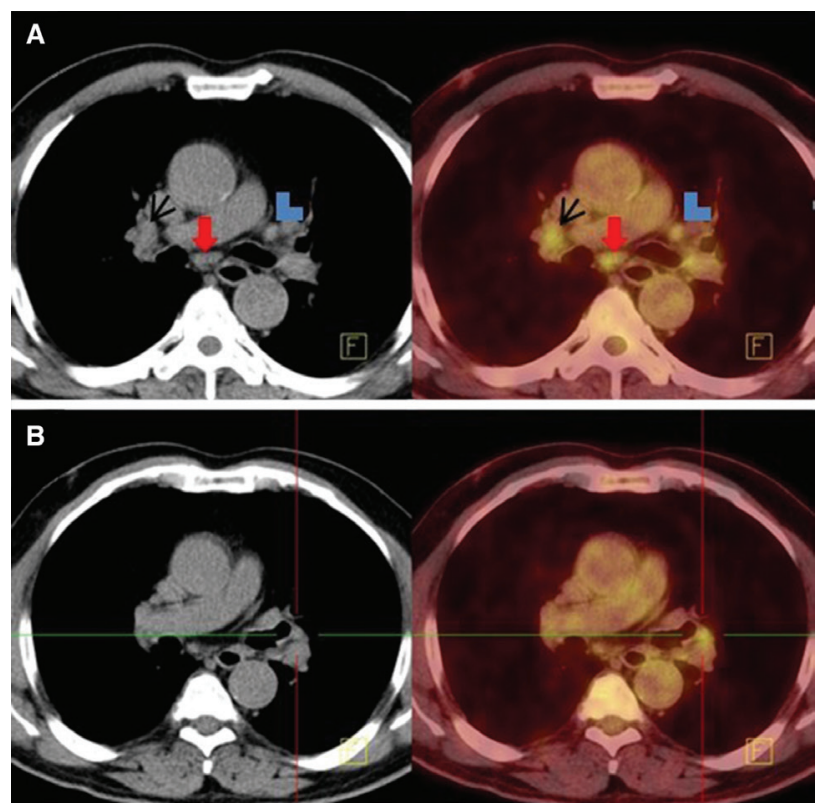

Figure 2. $A$ and $B$ demonstrate axial sections of $C T$ and fused PET/CT images in the patient with lung adenocarcinoma. Right hilar [black arrow in $A$, maximum standardized uptake value $\left(S \cup V_{\text {max }}\right): 4.1$ ], subcarinal (red arrow in A, SUV max: 4.2) and left interlobar hypermetabolic lymph nodes (in $B$, SUV $_{\text {max }}: 3.8$ ) seen on fused PET/CT were evaluated as anthracosis using histopathologic sampling. The hypermetabolic subaortic lymph

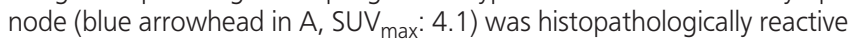

patient was down-staged. When assessed on a patient-bypatient basis, hilar and interlobar lymph nodes were most commonly recorded as false-positives on 18F-FDG PET/CT (in $66 \%$ of patients with false-positive lymph nodes). A total of 20 distant metastatic sites (eight bone, five liver, three surrenal gland, two brain, one spinal, one pons metastases) were detected in 14 patients (28\% of all patients) by $18 \mathrm{~F}-\mathrm{FDG}$ PET/CT . Of these metastases, $12 / 20$ (60\%) could only be detected by $18 \mathrm{~F}-\mathrm{FDG}$ PET/CT. When evaluated on a patient-by-patient basis, in 14\% (7/50) of all patients, distant metastases were detected only by $18 \mathrm{~F}-\mathrm{FDG}$ $\mathrm{PET} / \mathrm{CT}$.

18F-FDG PET/CT led to a change in treatment plan based on conventional methods in $17 / 50$ (34\%) patients. Through conventional staging, 11 of these 17 patients were classified as "at a potentially operable" stage (stage 1-3A), five were classified as "at a potentially inoperable" stage (stage 3B-4), and one patient had a lesion that was assessed to be benign by conventional methods. Within the group of 11 patients classified as "at a potentially operable" stage, four had N3 lymph node metastases and five had distant metastases as identified by 18 F-FDG PET/CT. As a result, these patients underwent chemotherapy thus avoiding unnecessary surgery in $9 / 50(18 \%)$ patients. In the other two patients, N1 lymph node metastasis was detected by 18F-FDG PET/CT, and neoadjuvant chemotherapy was started prior to the operation. Within the group of five patients who were classified as "at a potentially inoperable" stage, three were identified with M1 disease by conventional staging. The areas considered as distant metastases in these three patients were interpreted as benign by $18 \mathrm{~F}-\mathrm{FDG}$ PET/CT and thus were accepted as candidates for curative treatment. The other two patients were categorized as stage 3B by conventional methods and were thus planned for chemotherapy and localized radiotherapy. However, distant metastases were detected by $18 \mathrm{~F}-\mathrm{FDG}$ PET/CT in these two patients who underwent chemotherapy and palliative radiotherapy. Another patient had a lesion that was interpreted as benign by conventional methods while the 18F-FDG PET/ $\mathrm{CT}$ evaluated this mass as malignant, and the patient was started on chemotherapy. The impact of 18F-FDG PET/CT on patient management is listed in Table 1. Finally, the correlation between $S U V_{\max }$ value of the primary lesion and patient survival was evaluated in 30 patients, one of whom was the patient who had synchronous double primary lung cancers. Primarily, the median $S U V_{\text {max }}$ (median SUV max $=15.6$ ) was calculated and accepted as the "cut-off" value. The mean survival time was $10.3 \pm 2.2$ months in patients with $S U V_{\max }<15.6$, and 15.9 1.6 months in those with $S U V_{\max } \geq 15.6$. There was no significant difference between the two groups in terms of survival $(p=0.118)$ (Figure 3$)$. 


\section{Discussion}

Lung cancer is the most common cause of cancer-related death worldwide, and early diagnosis is important for the application of curative treatments. 18F-FDG PET/CT is used commonly to differentiate benign and malignant lung lesions. Gupta et al. (4) reported the sensitivity and specificity of 18F-FDG PET/CT in benign-malignant distinction of indeterminate solitary pulmonary nodules as $93 \%$ and $88 \%$, respectively. 18F-FDG PET/CT might yield a false positive result in inflammatory conditions, tuberculosis or granulomatous lesions. A false negative 18F-FDG PET/CT result is generally associated with nodules measuring less than $1 \mathrm{~cm}$, carcinoid tumors or bronchoalveolar carcinomas (BAC) $(5,6,7,8,9)$. In our study, 18F-FDG PET/CT provided a true positive result in $94 \%$ and a false negative result in $6 \%$ of 51 lesions. The tumors with a false negative 18F-FDG PET/CT included two adenocarcinomas $(0.6 \mathrm{~cm}$ and $1.3 \mathrm{~cm})$ and one carcinoid tumor $(1 \mathrm{~cm})$. The small size and presence of a carcinoid tumor may have contributed to the false negative results. In the present study, the sensitivity, accuracy and positive predictive value of 18F-FDG PET/CT in the detection of primary malignancy were calculated as $94 \%, 94 \%$ and $100 \%$, respectively. These results are consistent with that reported in the literature. Several studies indicated that the mean SUV and SUV $\max$ differ according to histologic subtypes of lung cancer. In particular, it has been reported that the $S U V_{\max }$ of carcinoid tumors and BAC are low $(10,11)$. Vesselle et al. (12) found that the $S U V_{\max }$ of BAC was lower than all other subtypes, and that non-BAC adenocarcinomas had lower SUV $V_{\text {max }}$

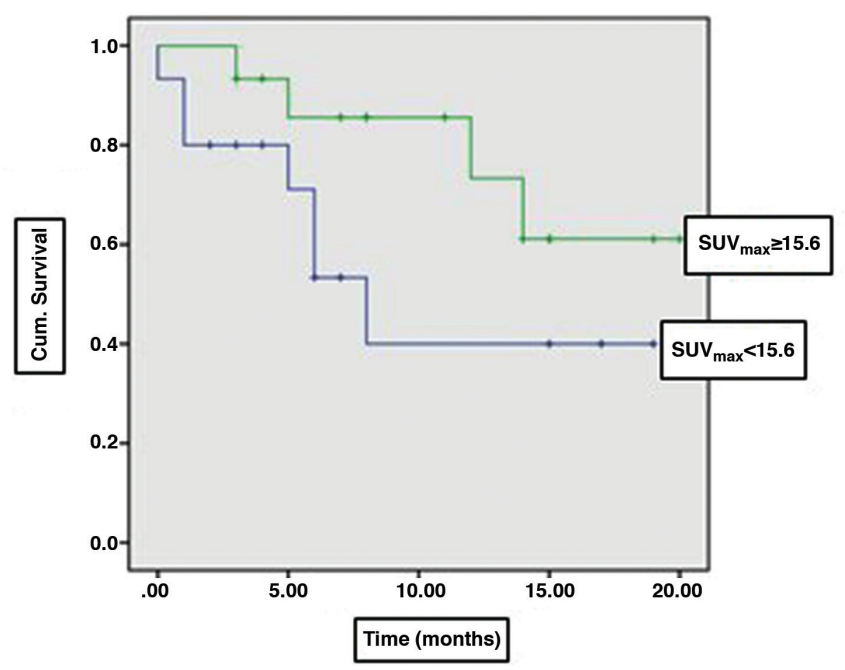

Figure 3. Survival curves of patients according to their maximum standardized uptake value ( $\left.S \cup V_{\max }\right)$ values; there was no significant difference in terms of mean survival time between $S U V_{\max }$ values below

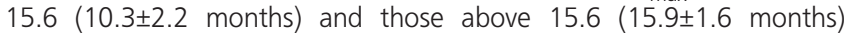
$(p=0.118)$ values than SCC. The majority of studies in the literature report that the $S U V_{\max }$ of adenocarcinomas is lower than that of SCCs $(13,14)$. However, in our study, no statistically significant difference was identified between adenocarcinoma $(16.8 \pm 13.5)$ and SCC (17.9 \pm 5.6$)$ in terms of mean $S U V_{\max }(p=0.2)$. Several studies showed that tumor size is a prognostic factor for survival in NSCLC (15). The correlation between tumor size and SUV max has been previously assessed $(16,17)$. Zhu et al. (18) reported a moderate positive correlation between SUV $V_{\max }$ value and tumor size $(r=0.642, p<0.001)$. In our study, a positive correlation $(p=0.002)$ was identified between tumor size and $S U V_{\max }$, in line with findings of the earlier studies.

The detection of both lymph node and distant metastases is essential for proper staging in lung cancer. The sensitivity of 18F-FDG PET/CT in lymph nodes greater than $1 \mathrm{~cm}$ is high, although the accuracy and specificity rates are low (19). In a study by Detterbeck et al. (20), the false positive rate of PET in mediastinal lymph nodes was reported to be $13-22 \%$, and the false negative rate as $5-8 \%$. In our study, histopathologic lymph node evaluation was carried out in 21 of the 50 patients, and $52 \%$ of the 21 patients were correctly staged by $18 \mathrm{~F}-\mathrm{FDG}$ $\mathrm{PET} / \mathrm{CT}$ whereas the rate of patients incorrectly downstaged or up-staged by 18 F-FDG PET/CT were detected as $19 \%$ and $28 \%$, respectively. In our study, the false positive and false negative lymph node rates in 18F-FDG $\mathrm{PET} / \mathrm{CT}$ were found to be higher than that reported in the literature. This finding may be attributed to the fact that histopathologic evaluation was not performed in all lymph nodes evaluated as either positive or negative by 18F-FDG PET/CT. Furthermore; sarcoidosis, amyloidosis, anthracosis, tuberculosis and organized pneumonia may cause false positive results in lymph nodes. In one patient with a false positive lymph node on 18F-FDG PET/ $\mathrm{CT}$, histopathologic sampling revealed anthracosis. In addition, pulmonary infections or granulomatous diseases such as tuberculosis or sarcoidosis that are frequent in our country might have contributed to these outcomes. Further investigation of lymph node and distant organ metastases, particularly in patients being considered for surgical therapy, could prevent unnecessary surgery. Van Tinteren et al. (21) reported that performing an 18F-FDG $\mathrm{PET} / \mathrm{CT}$ in addition to conventional methods as part of preoperative staging of NSCLC might avoid unwarranted surgery in one-fifth of patients. In a study on patients with NSCLC, an 18F-FDG PET/CT led to a change in disease stage as determined by conventional methods in $50.6 \%$ (41.1\% up-staged, $9.5 \%$ down-staged) of patients, and alteration in treatment planning in $42.3 \%$ (22). In our study, the 18F-FDG PET/CT resulted in a change in the treatment plan as decided by conventional methods in $34 \%$ of all patients, and unnecessary surgery was prevented in $18 \%$ of the patients. In $6 \%$ of the 
patients, the 18F-FDG PET/CT was interpreted as negative for areas identified as metastasis through conventional methods, leading patients to possible curative therapy. In various studies, SUV $\max$ of the primary tumor detected by 18 F-FDG PET/CT was used to predict lung cancer prognosis and assess patient survival $(23,24)$. Ahuja et al. (25) found that patients with primary tumors showing a high FDG uptake had lower survival rates than those with a low uptake, while Hoang et al. (26) found no significant association between FDG uptake of the primary tumor and survival in patients with advanced NSCLC. In a metaanalysis published by IASLC in 2008, the SUV $\max$ of the primary tumor was a strong determinant of prognosis in NSCLC. However, the need to support this finding with multivariate analysis was emphasized (27). The present study evaluated the relationship between $S U V_{\max }$ of the primary tumor and patient survival and no significant difference was identified between those with $S U V_{\max }$

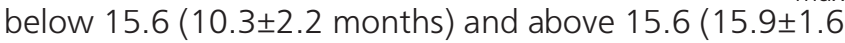
months) in terms of mean survival time $(p=0.118)$. Several previous studies support our findings, although a larger number of authors argue that SUV $V_{\text {max }}$ could be used to predict prognosis and assess survival in case of lung cancer. Our results might be related to the limited number of patients in the study as well as the differences between the two groups (e.g. age, genetic factors, stage, tumor pathology).

\section{Conclusion}

Despite the limitations of our study, such as limited number of patients, most of the results are consistent with previous studies. In our study, it is concluded that 18F-FDG PET/CT contributes to both the diagnosis and management of lung cancer by providing valuable information in addition to conventional methods.

\section{Ethics}

Ethics Committee Approval: The study protocol was approved by the Ethics Committee of Clinical and Laboratory Researches of Ege University Faculty of Medicine with decision number: 14-4.2/16 dated: 12.06.2014.

Informed Consent: Informed consent was waived due to the retrospective design of the study.

Peer-review: Externally peer-reviewed.

\section{Authorship Contributions}

Concept: E.B., Design: E.B., A.A., Data Collection or Processing: E.B., G.Ç., A.A., Analysis or Interpretation: E.B., G.C.., A.A., Literature Search: E.B., A.A., Writing: E.B., A.A.

Conflict of Interest: No conflict of interest was declared by the authors.

Financial Disclosure: The authors declared that this study received no financial support.

\section{References}

1. Dela Cruz CS, Tanoue LT, Matthay RA. Lung Cancer: Epidemiology, Etiology, and Prevention. Clin Chest Med 2011;32:605-644.

2. Jemal A, Siegel R, Ward E, Hao Y, Xu J, Thun MJ. Cancer statistics, 2009. CA Cancer J Clin 2009;59:225-249.

3. Purandere NC, Rangarajan V. Imaging of lung cancer: Implications on staging and management. Indian J Radiol Imaging 2015;25:109-120.

4. Gupta NC, Maloof J, Gunel E. Probability of malignancy in solitary pulmonary nodules using fluorine-18-FDG and PET. J Nucl Med 1996;137:943-949.

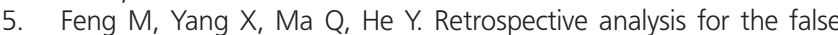
positive diagnosis of PET-CT scan in lung cancer patients. Medicine (Baltimore) 2017:96:e7415.

6. Herder GJ, Van Tinteren H, Comans EF, Hoekstra OS, Teule GJ, Postmus PE, Joshi U, Smit EF. Prospective use of serial questionnaires to evaluate the therapeutic efficacy of 18F-fluorodeoxyglucose (FDG) positron emission tomography (PET) in suspected lung cancer. Thorax 2003;58:47-51.

7. Chang JM, Lee HJ, Goo JM, Lee HY, Lee JJ, Chung JK, Im JG. False Positive and False Negative FDG-PET Scans in Various Thoracic Diseases. Korean J Radiol 2006;7:57-69.

8. Long NM, Smith CS. Causes and imaging features of false positives and false negatives on 18F-PET/CT in oncologic imaging. Insights Imaging. 2011:2:679-698.

9. Bunyaviroch T, Coleman RE. PET Evaluation of Lung Cancer. J Nucl Med 2006:47:451-469.

10. Liu Y. Lung Neoplasms with Low F18-Fluorodeoxyglucose Avidity. PET Clin 2018:13:11-18.

11. Meirelles GS, Capobianco J, de Oliveira MA. Pitfalls and artifacts in the interpretation of oncologic PET/CT of the chest. Radiol Bras 2017:50:55-59

12. Vesselle $H$, Salskov $A$, Turcotte $E$, Wiens $L$, Schmidt $R$, Jordan $C D$, Vallières $E$, Wood $D E$. Relationship between non-small cell lung cancer FDG uptake at PET, tumor histology, and Ki-67 proliferation index. J Thorac Oncol 2008;3:971-978.

13. Wang Y, Ma S, Dong, Yao Y, Liu K, Zhou J. Evaluation of the factors affecting the maximum standardized uptake value of metastatic lymph nodes in different histological types of non-small cell lung cancer on PET-CT. BMC Pulm Med 2015:15:20.

14. Lu P, Yu L, Li Y, Sun Y. A correlation study between maximum standardized uptake values and pathology and clinical staging in nonsmall cell lung cancer. Nucl Med Commun 2010;31:646-651.

15. Mery CM, Pappas AN, Burt BM, Bueno R, Linden PA, Sugarbaker DJ, Jaklitsch MT. Diameter of non-small cell lung cancer correlates with long-term survival: implications for T stage. Chest 2005;128:32553260.

16. Liu Y, Wu N, Bi GC, Zhang DS, Zheng R, Liang Y, Zhang WJ, Li XM, Fang Y. Correlation analysis between 18F-FDG uptake features and the prognosis in patients with pathologic stage lung adenocarcinoma. Zhonghua Zhong Liu Za Zhi 2016;38:263-269.

17. Sunnetcioglu A, Arisoy A, Demir Y, Ekin S, Dogan E. Associations between the standardized uptake value of (18)F-FDG PET/CT and demographic, clinical, pathological, radiological factors in lung cancer. Int J Clin Exp Med 2015;8:15794-15800.

18. Zhu SH, Zhang Y, Yu YH, Fu Z, Kong L, Han DL, Fu L, Yu JM, Li J. FDG $P E T-C T$ in non-small cell lung cancer: relationship between primary tumor FDG uptake and extensional or metastatic potential. Asian Pac J Cancer Prev 2013;14:2925-2929.

19. Al-Sarraf N, Gately K, Lucey J, Wilson L, McGovern E, Young V. Lymph node staging by means of positron emission tomography is less accurate in non-small cell lung cancer patients with enlarged lymph nodes; Analysis of 1145 lymph nodes. Lung cancer 2008;60:62-68.

20. Detterbeck F, Falen S, Rivera PM, Halle JS, Socinski MA. Seeking a home for a PET, part 2: Defining the appropriate place for positron emission tomography imaging in the staging of patients with suspected lung cancer. Chest 2004;125:2300-2308. 
21. Van Tinteren $H$, Hoekstra OS, Smit EF, Van Den Bergh JH, Schreurs AJ, Stallaert RA, Van Velthoven PC, Comans EF, Diepenhorst FW, Verboom P, Van Mourik JC, Postmus PE, Boers M, Teule GJ. Effectiveness of positron emission tomography in the preoperative assessment of patients with suspected non-small cell lung cancer: the PLUS multicentre randomised trial. Lancet 2002;359:13881393.

22. Gregory DL, Hicks RJ, Hogg A, Binns DS, Shum PL, Milner A, Link $E$, Ball DL, Mac Manus MP. Effect of PET/CT on Management of Patients with Non-Small Cell Lung Cancer: Results of a Prospective Study with 5-Year Survival Data. J Nucl Med 2012;53:1007-1015.

23. Hattori A, Matsunaga T, Takamochi K, Oh S, Suzuki K. Clinical Significance of Positron Emission Tomography in Subcentimeter NonSmall Cell Lung Cancer. Ann Thorac Surg 2017;103:1614-1620.

24. Liu J, Dong M, Sun X, Li W, Xing L, Yu J. Prognostic Value of 18F-FDG PET/CT in Surgical Non-Small Cell Lung Cancer: A Meta-Analysis. PLoS One 2016;11:e0146195.
25. Ahuja V, Coleman RE, Herndon J, Patz EF Jr. The prognostic significance of fluorodeoxyglucose positron emission tomography imaging for patients with nonsmall cell lung carcinoma. Cancer 1998;83:918-924.

26. Hoang JK, Hoagland LF, Coleman RE, Coan AD, Herndon JE, Patz EF Jr. Prognostic Value of Fluorine 18 Fluorodeoxyglucose Positron Emission Tomography Imaging in Patients With Advanced-Stage Non Small-Cell Lung Carcinoma. J Clin Oncol 2008;26:1459-1464.

27. Berghmans $T$, Dusart $M$, Paesmans $M$, Hossein-Foucher C, Buvat $I$, Castaigne C, Scherpereel A, Mascaux C, Moreau M, Roelandts M, Alard S, Meert AP, Patz EF Jr, Lafitte JJ, Sculier JP; European Lung Cancer Working Party for the IASLC Lung Cancer Staging Project. Primary tumor standardized uptake value (SUVmax) measured on fluorodeoxyglucose positron emission tomography (FDG-PET) is of prognostic value for survival in non-small cell lung cancer (NSCLC): a systematic review and meta-analysis (MA) by the European Lung Cancer Working Party for the IASLC Lung Cancer Staging Project. J Thorac Oncol 2008;3:6-12. 